\title{
worldview
}

A JOURNAL OF RELIGION AND INTERNATIONAL AFFAIRS

\section{VARIETIES OF UTOPIANISM}

In an essay published several years ago, Ignazio Silone wrote of the dilemma of modern man in search of political meaning. "The last forty years," he observed, "have witnessed the collapse of most of the great politico-social myths bequeathed to us by the nineteenth century. As a result, certain kinds of people who had relied on these myths as a compass find themselves in a state of spiritual vagueness and ambiguity."

The myths which have died are, of course, the utopian myths of nineteenth century progress. Liberal optimism was intellectually respectable before the first world war. A man who proclaims it now-after the concentration camps, the gas chambers and the hydrogen bomb-advertises himself as a man who has somehow escaped the modern world. Because to have known modern history is to have been schooled in the tragic sense of life.

In the tragedy of modern history, and in the continuing threats to civilization which are everywhere about, we have relearned a respect for power. We have found out that a world can be sanitized and mechanized and even chromium plated, and still remain a jungle-and in a jungle only a fool moves unarmed. One still finds little groups of utopians here and there, proclaiming their doctrine of salvation through persuasion and love; but they are lonely and lost among the masses of those who have learned the lessons of this century well. Nowhere are utopians in power; everywhere "realists" guide our destinies, armed with weapons that may make a quick finish to all the troubles of our race.

In this issue of Worldview, an uncompromising "realist" position is stated and, along with it, an attack on "utopian" temptations is made. In his essay "Politics and Utopia," Mr. Thomas Molnar argues that in their impatience to make the world over to their hearts' desire, the utopianreformists (who, he believes, are still numerous among us) ignore the hard, given facts of international life. He thinks that they-the idealists, the dreamers-are ready, for the sake of their illu- sions, to weaken our defenses, to retreat, to appease, and, finally, to deliver us over to our enemies. It is the mission of the realists, $\mathrm{Mr}$. Molnar says, to insist on facing the world as the world actually is, to see that it is a place where power still prevails, and to be ready to fight, with thermonuclear weapons, if necessary. The neopacifists tell us that in a fearful choice between thermonuclear war and surrender we must, for the sake of humanity, choose surrender. No, says Mr. Molnar: we must choose thermonuclear war.

The collapse of liberal mythology has thus, in this view, returned us, full force, to power as the implacable arbiter of our destiny. Utopianism, with all its hopes, is dead, and where it is not dead, it is dangerous. Let us therefore "stand firm" everywhere. Our only prospect, apparently, is to grit our teeth and wait. And if the worst comes, well, we will at least have acted honorably; human existence isn't the ultimate value after all.

-

In advancing his argument, Mr. Molnar undoubtedly states a view that is shared by large numbers of Americans. Much of our popular rhetoric is based on a similar concept of the "real" issues in the world. If, in a poll, Americans were asked "How must we stand?" there is no question but that most of them would reply, "Firm." But in agreeing to Mr. Molnar's stricture on "utopianism," it seems necessary to bring his concept of "utopian" up to date. Because the classic utopianism which Mr. Molnar describes is a sorry, belabored thing, and few could be found to defend it for the past forty years.

What are some modern varieties of utopianism? At the head of any list, we think, one should find a certain concept of power. In a world of thermonuclear weapons, power conceived as an answer to the problems that face us partakes of the nature of utopianism.

There was a time in the world's history, certainly, when, in the face of hostile forces, one 
could realintically urge warfare, if necessary, as a viable alternative to tyranny. That time is past. A war fought with thermonuclear weapons of mass destruction would be different in kind from all previous wars, because, unlike previous wars, it would threaten the continued existence of the human race. Power alone, therefore, is no longer a practical scheme of political salvation. Those who fail to see this, who continue to urge power as some kind of "answer" to world disorders are, most certainly, utopians.

Isolationism, too, has in our time become a form of utopianism. The concept of a fortress civilization is comforting; it is also folly. Modern technology has shrunk the world and destroyed "safe" boundaries. Those who think that values can be defended in geographical isolation from what is happening, so quickly, all over the planet are also utopians.

And surely the pathetic dream of Western hegemony, of a continued colonialism, has become the besetting utopianism of those who cannot yet see what is the political-social phenomenon of our century; the revolution of formerly depressed peoples of Asia and Africa. Because it is this phenomenon which, more than any other, may influence the course of history for centuries ahead-if all of us together are not blown up before other centuries dawn.

Warnings against utopianism-against impractical visions of political reality-are always in order. We must all, indeed, be realists. But we must be careful that our catalogue of utopianisms and our glossary of realisms are kept upto-date.

\section{MR. MKOYAN'S hOLIDAY}

The visit to American shores by Soviet Deputy Premier Anastas I. Mikoyan is without precedent in the decade-long Cold War. Yet, before it was half over, as it is at this writing, the visit had the entire West speculating upon its significance in lessening (or increasing) international tensions.

Mr. Mikoyan's "holiday," as he himself terms it, takes place at a time when the Soviet Union's bellicose ultimatum that the West abandon Berlin is still ringing in American ears. Because of this, his visit is being read as an attempt to assess the American reaction to that and if possible to soften it with reminders of earlier Soviet calls for an end to nuclear tests, disarmament, and an increase in peaceful trade between the U.S. and the USSR. A short visit with Secretary Dulles at the beginning of his tour, and a talk with President Eisenhower at its close will give Mikoyan ample opportunity to make his purposes plain to the Administration.

If this is his task, it has been made easier since he arrived by the Kremlin's call for a meeting in Prague or Warsaw to discuss, not alone the Berlin question, but a broad range of issues contributing to international tension. Clearly, the Soviet plan for a "free city of Berlin" has met a unified stone wall of Western resistance. Without the economic means to exist independently, a free Berlin would topple into the Soviet camp within a few months. Here, again, Mikoyan has been useful by describing the Soviet ultimatum as a "bargaining position."

Whatever immediate political purposes lurk behind his presence in our midst, it is perhaps useful to remember that Mr. Mikoyan's holiday takes place just as this country is emerging from its third post-war recession while his own nation is attempting to obliterate the memory of its last and ill-starred Five Year Plan by launching a new and even more ambitious Seven Year Plan.

In this race for economic and industrial superiority to the United States, nothing would be more useful to the 21st Congress meeting in Mos. cow late in January than a first hand report from a Deputy Premier on the general health of the current champion. Thus, Mikoyan has fled the cocktail parties and pleasure domes of Washing. ton and New York to concentrate on meeting industrial leaders and businessmen in the hinterlands; a recipient of his close scrutiny withm hours after he stepped off his plane was a doughnut-making machine.

Patently, reduced Cold War tensions would allow Soviet leaders to pour funds from their military budget into the race for industrialization. By his geniality and good humor, Mikoyan may well be attempting to create a climate that will make another conference between the U.S. and the USSR seem worthwhile, providing a sound basis for reduced armament.

If that is his task, Mikoyan is performing well, despite cold shoulders from the Administration in Washington on the one hand and hot-headed, angry Hungarian pickets on the other. There is a case for a hands-off attitude by Washington: Mikoyan has insisted his visit is "unofficial," and without specific purpose; and, surely, there is a refreshing contrast between his visit and the carefully guided tours available to visitors to the 
Soviet Union. But unofficial or not, Mr. Mikoyan's tour is being carefully covered by foreign correspondents who are reporting to capitals abroad. The absence of official U.S. representation in the Mikoyan party will certainly be misread by peoples in allied and neutral countries.

On top of this, the behavior of Hungarian patriots does little credit to the righteousness of their cause. Egg-throwing, bomb threats and personal abuse reduce the high tragedy of Hungary to farcical and meaningless dimensions. The suc- cess of the pickets has been due in no small degree to the failure of Washington to provide adequate security measures to a high dignitary of a foreign state. When similar incidents happened to our own Vice President abroad several months ago, there was a rattling of weapons and a call to the Marines. This parallel will not be missed by a watchful world, which still out of habit if not out of conviction looks to the United States for leadership in the battle against hunger, disorder and tyranny.

\section{in the magazines}

Hans. J. Morgenthau, writing in the New Republic for December 29, calls on the Eighty-sixth Congress to assume leadership in mounting a national policy that will meet the Soviet challenge on all fronts. His article, "The Last Years of Our Greatness?" attacks the Administration for having "erected the balanced budget to the measure of all policy." And he writes, "The issue which must for us overshadow all others is not how to save money but, first, how to survive and, then, how to emerge victorious from this contest. The nations which would persuade itself that it cannot afford the policies which would assure its survival would have forfeited its claim to greatness and jeopardized its very existence as well."

The Executive Branch of the government, charges Professor Morgenthau, has become an unwieldy assortment of delegated, and conflicting, powers, incapable of the "swift, decisive, coordinated action [and] instantaneous responses to sudden challenge" which are needed to counter the menace of Soviet efficiency. In urging the initiative upon Congress, Professor Morgenthau notes that "Congressional government is a poor way of governing a great nation in the most perilous period of its history." But such are the political conditions of the day that "we have to choose, alas, not between Presidential and Congressional government, but between Congressional government and no effective government at all."

In the December 22 issue of the New Leader, Denis Healey is also concerned to establish some economic solution to the continuing Soviet threat.

So far, Mr. Healey finds, the West is failing in its "double task-to set Asia ah example of economic growth more impressive than that of Russia, and to help Asia to follow that example." He points out that, not only does Asia depend largely on the markets provided by the developed industrial countries, but that the strengthening of Asian economies would, in turn, be a stimulus to growth in the West. Neither the international stabilization of commodity prices nor the establishment, on a limited regional basis, of such enterprises as the European Common Market would be of any great help in the long run. A "global economic response" is what we need, even though it "will require the abandonment of dearly cherished economic dogmas."

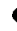

"Faith and Responsibility" is the subject of an eloquent article by John $\mathrm{C}$. Bennett in the December 3 issue of the Christian Century. Dr. Bennett considers three areas where religious faith and insight are engaged by social and political problems: the area of racial justice-"an inescapable personal problem for Christians"; the dilemmas of foreign policy - "basic rethinking is necessary"; and the anxieties of the cultural situation-here "the pastoral and the prophetic functions of the church meet."

In his discussion of foreign policy, Dr. Bennett cites some of the most dangerous aspects of our current thinking-the obsession with nuclear armaments, the failure to realize that the real struggle with Communism is political and economic rather than military, the American tendency toward "offensive self-righteousness" in dealing with other nations, the unwillingness to "accept the fact that two great Communist nations exist and will continue to exist" and that "as nations they have legitimate interests and reasonable fears."

With the aid of the church we may administer possible correctives; but commitments to social rosponsibility which are based on faith and theology are not "guarantees of success. We are called to obey what we believe to be God's will for us in humility and love, and to employ every available means to discover the wisest policies." PAMPHILUs 